\title{
Investigation of Renal Function in Liver Transplant Patients: MDRD or Cockroft-Gault?
}

\author{
PETRA PÁJER, IMRE FEHÉRVÁRI
}

Department of Transplantation and Surgery, Semmelweis University, Budapest, Hungary

\begin{abstract}
Both acute and chronic liver diseases have an effect on renal function. After liver transplantation we have to pay attention to the further loss of function because of applied calcineurin inhibitor treatment. It has a nephrotoxic side-effect, so the investigation of renal function is converted into an important mission in liver transplant patients. In our study we compared the results between formulas which use serum creatinine: MDRD, which use albumin too, has effectively other values than the Cockroft-Gault. We compared the two formulas in a retrospective analysis, in 187 patients at a stated time (before operation, after operation, l week, l month after transplantation). We got higher GFR at each date with Cockroft-Gault: mean difference $19.56 \%, 17.33 \%, 37.18 \%$ and $28.8 \%$. In the range of $15-60$ $\mathrm{ml} / \mathrm{min}$ GFR, we found nearly twice as many patients by MDRD than by Cockroft-Gault. Median with MDRD: $79 \mathrm{ml} / \mathrm{min}, 65.1 \mathrm{ml} / \mathrm{min}, 52 \mathrm{ml} / \mathrm{min}, 49.5 \mathrm{ml} / \mathrm{min}$; median with Cockroft-Gault: $93.8 \mathrm{ml} / \mathrm{min}, 78 \mathrm{ml} / \mathrm{min}, 70.1 \mathrm{ml} / \mathrm{min}, 69.4 \mathrm{ml} / \mathrm{min}$, all are significant $(p<0.001)$. Many previous studies have already compared the two formulas in end-stage kidney disease. On the basis of these studies MDRD is also suitable under $30 \mathrm{ml} / \mathrm{min}$ GFR, but Cockroft-Gault formula just above it approached the real GFR measured with isotope methods. We got the similar conclusion in the examined patient group. It can be stated that MDRD is more suitable to determine renal function in liver transplant patients.
\end{abstract}

Keywords: liver transplantation, MDRD, Cockroft-Gault

\begin{abstract}
Abbreviations
$\mathrm{CKD}=$ chronic kidney disease $; \mathrm{CV}=$ cardiovascular; $\mathrm{GFR}=$ glomerular filtration rate; $\mathrm{eGFR}=$ estimated glomerular filtration rate; MELD $=$ Model for Endstage Liver Disease NSAID $=$ NonSteroidal AntiInflammatory Drug; MDRD = Modification of Diet in Renal Disease; NIST = National Institute of Standards and Technology; Scr = serum creatinine; MLDT = Magyar Laboratóriumi és Diagnosztikus Társaság, Hungarian Association of Laboratory Medicine and Clinical Chemistry; MANET = Magyar Nefrológiai Társaság, Hungarian Nephrology Association
\end{abstract}

Corresponding address: Imre Fehérvári MD, Baross u. 23, H-1082 Budapest, Hungary.

E-mail: fehervar@trans.sote.hu 
Table 1 The stages of chronic kidney disease

\begin{tabular}{|c|c|c|c|c|}
\hline Stage & Parameter & GFR $\mathrm{ml} / \mathrm{min} / 1.73 \mathrm{~m}^{2}$ & Symptoms & eGFR control \\
\hline 1. & $\begin{array}{l}\text { kidney disease } \\
\text { with normal or high GFR }\end{array}$ & $>90$ & $\begin{array}{l}\text { basic disease, } \\
\text { marginal urine lab tests }\end{array}$ & \\
\hline 2. & $\begin{array}{l}\text { kidney disease } \\
\text { with reduced GFR }\end{array}$ & $60-89$ & $\begin{array}{l}\text { hypertension, } \\
\text { high CV risk }\end{array}$ & yearly \\
\hline 3. & moderate kidney disease & $30-59$ & $\begin{array}{l}\text { above }+ \text { anemia } \\
\text { serious CV risk }\end{array}$ & half-yearly \\
\hline 4. & serious kidney disease & $15-29$ & $\begin{array}{l}\text { above + hyperK } \\
\text { osteodyst., edema }\end{array}$ & 3 monthly \\
\hline 5. & ESKD & $<15$ or dialysis & $\begin{array}{l}\text { above + uremia } \\
\text { malnutrition }\end{array}$ & 1-3 monthly \\
\hline
\end{tabular}

$\mathrm{CV}$ = cardiovascular; hyperK = elevated serum potassium; $\mathrm{eGFR}=$ estimated glomerular filtration rate; $\mathrm{ESKD}=$ end-stage kidney disease

Liver transplantation is an universally conventional treatment of advanced liver diseases. The frequent alcoholic liver cirrhosis and HCC caused by hepatitis $\mathrm{C}$ or B viruses, metabolic or autoimmune diseases are main indications of transplantation. The results became better since the first transplantation. While twenty years ago $35 \%$ of the patients were alive at the end of the first postoperative year, nowadays it is more than $90 \%$ due to improvement of immunosuppressive treatment and surgical techniques. In spite of this, currently we still have to manage many complications, from which we attend to the decline of renal function in our study.

Chronic kidney disease (CKD), as defined by a reduction in the estimated glomerular filtration rate (GFR), is on the increase in Hungary, due to the greater prevalence of atherogenic (diabetes mellitus, hypertonia) nephropathy and the ageing of population. After liver transplantation we find further augmenting factors: on one hand the nephrotoxic calcineurin inhibitor (cyclosporin, tacrolimus) therapy, which prevents the rejection, on the other hand the operative procedure has an effect on renal function. Due to these factors, liver transplant recipients may reach the criteria of end-stage kidney disease (ESKD) (Table 1) influencing badly the survival after transplantation [1].

Recently, Fisher investigated incidence of CKD during immunosuppressive medication. Renal function was estimated from serum creatinine levels. There was an elevated risk of chronic renal failure among patients with either high daily or high cumulative cyclosporin levels. Fisher emphasized the importance of correct dosing of immunosuppressive treatment [2].

Many other factors have also an influence on renal failure. Two types may be distinguished: prerenal and intrinsic renal failure. Acute glomerulotubular balance disturbance, due to decrease of extracellular volume, belongs to the first type. Causes of decrease may involve hypalbuminemia, hypovolemia, vasodilatation and hepatorenal syndrome as a result of vasoconstriction of afferent arterioles. Loss of glomerular perfusion results in the reduction of urine production. It can be prevented by filling up the extracellular and circulating volume, so good circulation and its consequence, good glomerular filtration rate, are predictors of good renal function. The second type of failure is caused by diseases of the renal tissue itself: acute ischemia triggers acute tubular necrosis, while the nephrotoxic drugs, such as antibiotics, NSAIDs and immunosuppressants can result in acute interstitial nephritis. Therefore accurate determination of renal function is required in these patients. 
The liver transplant survival correlates with pretransplant renal function: poor outcomes are seen in patients in whom ESKD develops. We have to consider this before placing the patient on the waiting list [3]. In the Child-Pugh classification, which was used previously, the serum creatinine level is not found in the counted parameters. The basis of score is bilirubin, albumin, prothrombin, encephalopathy and ascites, then patients are classified in A, B or C stage. The Mayo Clinic made a more suitable classification: Model for Endstage Liver Disease (MELD) [4]. We use MELD to estimate who has more benefit than with risk of liver transplantation. The factors for calculating the score are: bilirubin, prothrombin (INR) and serum creatinine level [5]. After previous dialysis treatments the patients get maximum score influencing the prognosis: transplantation is not advisable either with a high score close to 40 , or with a low score. While in the first case the patient is in too poor status, in the second case in too good status for surgery. Patients get extra points and so the score is higher in hepatocellular carcinoma, hepatopulmonary syndrome, familiar amyloidosis and primary oxaluria, than the score expected on the basis of laboratory values. Unfortunately MELD classification has many limitations. First of all, in many cases it does not correlate with the patient's status as required: we got better prognosis with ascites, spontaneous bacterial peritonitis, variceal bleeding and encephalopathy. In addition, the MELD is unable to predict either living donor liver transplant recipient or graft survival in the first postoperative year [6]. For this reason many researchers tried to modify it. Kawaguchi et al. investigated the interaction between MELD score and body mass. They found that body mass was a powerful predictor [7]. Huo et al. offer to use MELD corrected creatinine for women. Moreover there are many current researches to find new prognostic factors [9, 10], like Lewsey et al. who have made a new estimating model to predict 90-day survival [11].

Traditionally, GFR has been considered the best marker of kidney function. In clinical practice, renal function is typically estimated from serum creatinine levels. The creatinine-based estimation equations (Cockcroft-Gault, MDRD) are more accurate. During the last few years different equations have been created in order to have a reliable, convenient and easy method to determine kidney function.

In the last few years cystatin $\mathrm{C}$ has been investigated as a prosperous factor. It is an endogenous molecule, involved in the metabolism of cysteine proteinases. It can be used as a marker of kidney function. It is especially important that cystatin $\mathrm{C}$ is produced by nearly all cells and its serum level, which correlates with renal function, is not affected by diet or other factors. In addition, we can apply special estimation formulas based on serum cystatin C (Hoek, Feller, Larsson). There were comparisons between these and previous methods, and according to initial results, cystatin $\mathrm{C}$ based calculations will be relevant in clinical practice [12].

Recently White et al. investigated the interaction between serum cystatin C, serum creatinine, creatinine clearance and real GFR measured with renal scintigraphy. They got a correlation between serum cystatin $\mathrm{C}$ and renal GFR in all stages of cirrhosis under $70 \mathrm{ml} / \mathrm{min}$, with a $80 \%$ sensivity and $80 \%$ specifity [13].

\section{Method}

We adopted equations based on different parameters to estimate creatinine clearance without 24 hours urine collection. The Cockcroft-Gault equation was the first developed, today it is widely known. Ten years ago MDRD (Modification of Diet in Renal Disease) equation was developed for use in patients with CKD (mean GFR $\sim 40 \mathrm{~mL} / \mathrm{min}$ ). Many modifications of the equation 
Table 2 Special states, in which regular evaluation of eGFR is critical

Verified or suspected chronic kidney disease

Medical diseases with high risk of asymptomatic CKD

(diabetes, hypertension, angiopathy)

Urological disease with obstructive uropathy

(prostate hyperplasia, gynecological tumor, recurrent renal calculus)

Potential nephrotoxic treatment, intervention

ACEI/ARB, NSAID, cyclosporin, tacrolimus, operations

Toxic drugs secreted by kidney

$\mathrm{CKD}=$ Chronic Kidney Disease ACEI $=$ Angiotensin Converting Enzyme Inhibitors; $\mathrm{ARB}=$ Angiotensin II Receptor Blockers; NSAID = NonSteroidal Anti-Inflammatory Drug

have been worked out to estimate the GFR. By use of this equation (eGFR) we can diagnose the severity of CKD and follow its progression (Table 2) [14]. Regular estimation of renal function is advised in cases of high risk of CKD even without symptoms.

Regular evaluation of eGFR among liver transplant patients is also critical [15]. But it is fundamental to determine the formula to be used for estimation, as the therapeutic and diagnostic procedures depend on real GFR.

The Cockroft-Gault formula, which was developed in 1976, is based on age, sex, body weight and height and serum creatinine level:

$$
\mathrm{Ccr}=(140-\text { age }) \times \mathrm{kg}) / 72 \times \mathrm{Scr}(\mathrm{mg} \%) \times 0.85 \text { (if woman }) .
$$

The great advantage of this formula is, that it is normalized to body surface area (BSA) and it is cheap and easy to count. Above $30 \mathrm{ml} / \mathrm{min}$ Cockroft-Gault is nearly corresponding to real GFR measured with isotope using direct methods, but under this rate it is false.

In 1999 the MDRD formula was developed. In the range of $15-60 \mathrm{ml} / \mathrm{min}$ GFR, we can estimate real GFR more accurately with this formula than with the previous equations. Several studies have confirmed that MDRD is more suitable than Cockroft-Gault to follow renal function among patients with end stage kidney disease (ESKD) [16]. In addition to the original 6variable MDRD formula, the abbreviated 4-variable MDRD formula was also developed to make estimation easy for use.

The 6-variable MDRD:

$$
\begin{aligned}
\mathrm{GFR} & =170 \times(\text { age })-0.176 \times(\mathrm{Scr} \times 0.0113)-0.999 \times(\text { urea } \times 2.8)-0,17 \times \\
& \times(\text { albumin } \times 0.1) 0.318 \times 0.762(\text { if woman }) \times 1.18(\text { if black race })
\end{aligned}
$$

The 4-variable MDRD:

$$
\begin{aligned}
\mathrm{GFR}= & 186 \times(\mathrm{Scr} \times 0.0113)-1.154 \times(\text { age })-0.203 \times(0.742 \text { if woman }) \times \\
& \times(1.21 \text { if black race })(\text { creatinine } \mathrm{mg} / \mathrm{dl}, \text { albumin } \mathrm{g} / \mathrm{dl})
\end{aligned}
$$

The 6-variable MDRD includes the following factors: age, sex, body weight, race and levels of serum creatinine, urea and albumin. On the one hand, serum creatinine correlates with GFR 


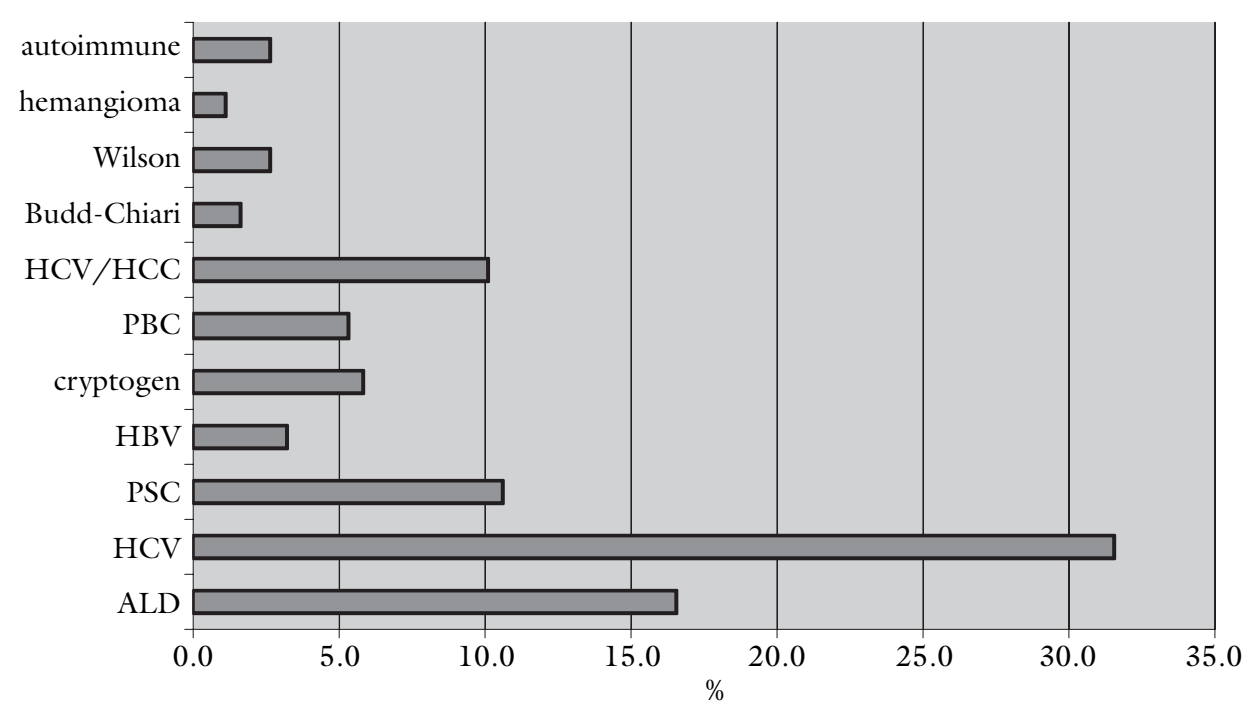

Fig. 1 The distribution of 187 liver transplant patients

in a hyperbolic way: decline of GFR by $50 \%$ generates only a low raise of serum creatinine. On the other hand, there are many factors, such as diet, renal hypoperfusion, liver failure, which have an effect on serum urea level. Among examined groups, we have to pay attention to a further important parameter of MDRD, which is albumin level. This formula was developed for patients with ESKD and in this group hypalbuminemia with ascites can be also detected so albumin has importance too. After liver transplantation the most common complications are bleeding and acute rejection. All of them can produce function failure, and as a consequence, the fall of albumin level. After all, the question is: is the MDRD - which uses albumin - more effective or not than Cockroft-Gault formula in the postoperative period.

In our retrospective study, renal function was analyzed in 187 liver transplant patients who were transplanted at our department between January 1, 2003, and December 31, 2007 (Fig. 1). 76 female and 111 male patients, aged between 18 and 68 years, were investigated,. We calculated the estimated glomerular filtration rate according to the 6-variable MDRD and Cockroft-Gault formula in the following timescale: before operation, after operation, 7 days after transplantation, 1 month after transplantation.

\section{Results}

We got higher GFR in every time period with Cockroft-Gault: mean difference 19.56\%, 17.33\%, $37.18 \%$ and $28.8 \%$, respectively. In the range of $15-60 \mathrm{ml} / \mathrm{min}$ GFR, we found nearly twice as many patients by using MDRD $(49,78,96,44$ patients) than by using Cockroft-Gault formula $(26,45,55,37$ patients). Median with MDRD: $79 \mathrm{ml} / \mathrm{min}, 65.1 \mathrm{ml} / \mathrm{min}, 52 \mathrm{ml} / \mathrm{min}, 49.5$ $\mathrm{ml} / \mathrm{min}$, median with Cockroft-Gault: $93.8 \mathrm{ml} / \mathrm{min}, 78 \mathrm{ml} / \mathrm{min}, 70.1 \mathrm{ml} / \mathrm{min}, 69.4 \mathrm{ml} / \mathrm{min}$ (Fig. 2). During the statistical analysis we found that the F-probe showed different standard devi- 

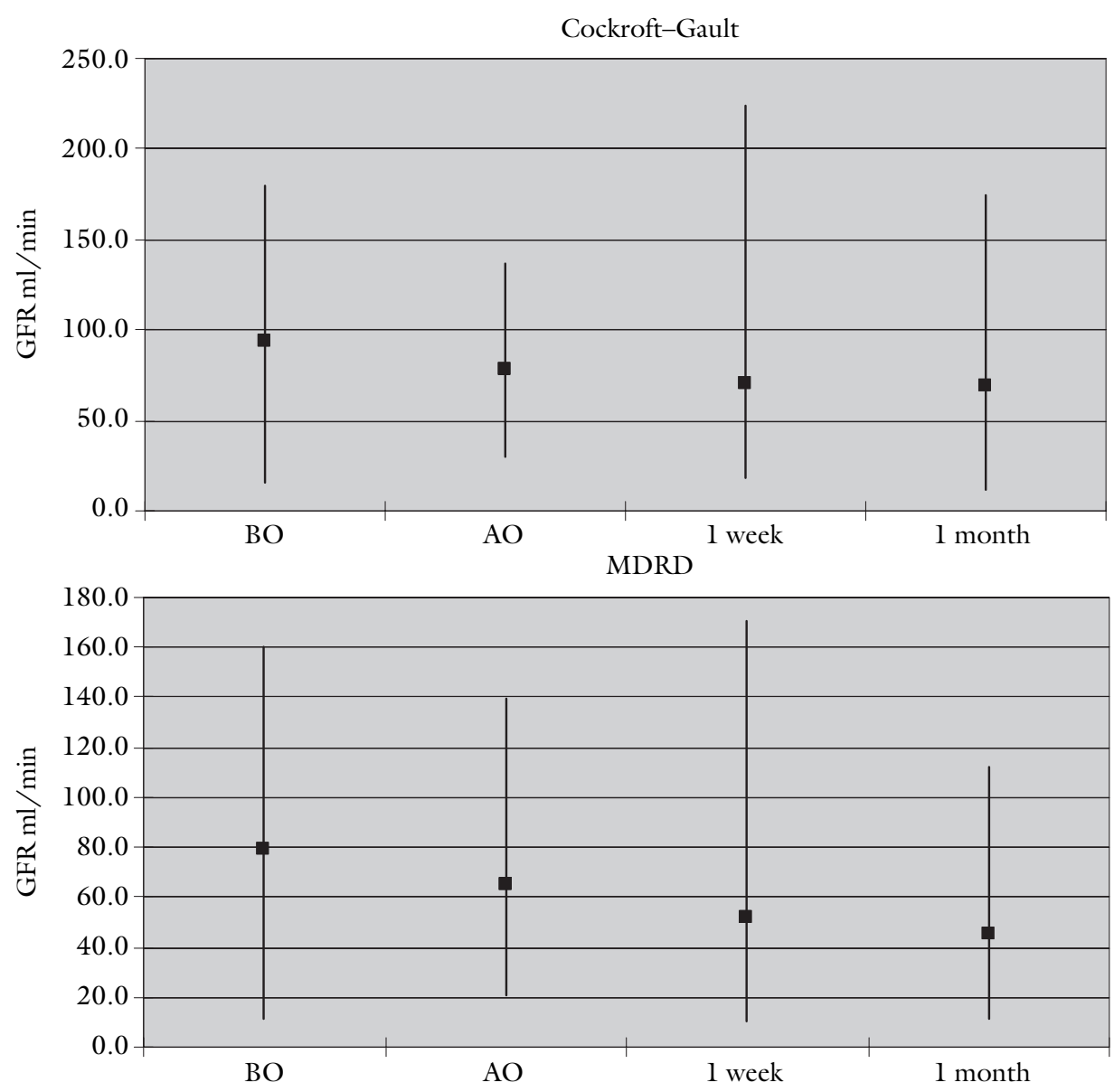

Fig. 2 Minimum, maximum and median scores with Cockroft-Gault and MDRD formula. BO = before operation; $\mathrm{AO}=$ after operation; median scores are signed with squares

ations by the two formulas. So the relationship between MDRD-GFR and Cockroft-Gault-GFR was examined by Welch analysis. We found all of them significant at each time point $(p<0.001)$.

\section{Conclusions}

On the basis of our investigation, we can decide which formula is more suitable to determine renal function in liver transplant patients. The 6-variable MDRD equation correlates with real GFR better than Cockroft-Gault as well under $60 \mathrm{ml} / \mathrm{min}$ as above $60 \mathrm{ml} / \mathrm{min}$. The Cockroft-Gault equation considerably overestimates renal function in both ranges, but especially in the low one. This is not acceptable among patients who have nephrotoxic treatment: early accurate detection of loss of renal function is especially important for them. It is possible to stop the decrease of GFR and to treat complications in time. 


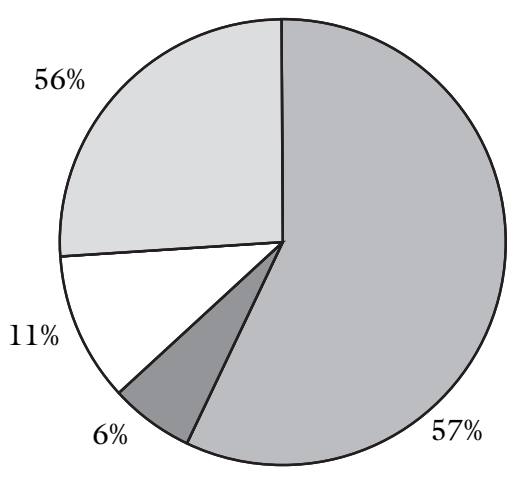

Jaffe kinetic $57 \%$

$\square$ enzymatic $6 \%$

Jaffe classic 11\%

$\square$ other $26 \%$

Fig. 3 National distribution of different creatinine measurement methods in 2005 (Origin: QualiCont LLC)

The advantage of the abbreviated 4-variable MDRD formula is that it is not necessary to know the body weight, body height or BSA. As a consequence of this, GFR can be calculated in laboratory in the knowledge of serum creatinine, age and sex. In 2005, MANET with MLDT worked out a recommendation, which offered to estimate GFR based on equations and to indicate results on laboratory report in routine way [17]. From the year 2006 the US and British guides have been suggesting application of eGFR calculated with MDRD [18]. Nowadays, there are more and more laboratories corresponding to these recommendations in Hungary too: due to the wide standardization of Scr assays, among every patient older than 18 years, eGFR is calculated on the basis of measured Scr, age and sex, supposing not black race.

Mátyus also emphasized the importance of calculation of GFR [19]. It is important that the Scr and eGFR should be done in the same laboratory, as there are different methods [20,21]. It is suggested to use 4-variable MDRD equation (186-MDRD) at the former classic Jaffe measuring, but with recent Jaffe kinetic or enzymatic method the 170-MDRD-equation is recommended. In our laboratory Jaffe kinetic method is applied. The national distribution of different methods is shown on Fig. 3.

In 2007, Poggio et al. analyzed several alternative possibilities to monitor renal function among patients who received kidney or other organ transplant. On the basis of their results, worse graft survival can be predicted in case of increased serum creatinine level. However, Scr measure laboratory methods should be standardized. This issue will be solved in the near future by the wide standardization of Scr assays, as recommended by the National Institute for Standardized Technology (NIST). In addition to this, Poggio et al. suggested to develop new formulas instead of present equations for liver transplant patients [22].

Many studies have already compared the usefulness of the two examined equations in different patient groups. As result, MDRD, which is based on more parameters, is more informative than Cockroft-Gault formula. Ruilope et al. reached the similar conclusion [23]. In their study, they investigated the relationship of cardiovascular death, proteinuria and GFR among high risk patients with hypertonia treated with valsartan. They reported that proteinuria was the best prognostic factor of $\mathrm{CV}$ risk under $60 \mathrm{ml} / \mathrm{min}$ apart from GFR calculating methods, but above it, they found better correlation between MDRD and CV outcome than with Cockroft-Gault. They offer to use MDRD to determine accurately $\mathrm{CKD}$, as a serious $\mathrm{CV}$ risk among patients with 
hypertonia: low GFR, less than $60 \mathrm{ml} / \mathrm{min}$, means equal risk as hypertension above 180/110 Hgmm, cholesterol level above $8.0 \mathrm{mmol} / \mathrm{l}$ or plaques without symptoms [24].

As regards our study, the use of MDRD formula is suggested instead of Cockroft-Gault formula. Several works have been tried to find the most suitable method to monitor renal function in deceased or living donor kidney transplant recipients or in patients with CKD or cirrhosis. These studies gave variable results: depending on the patient group, either MDRD based on serum creatinine or formulas based on cystatin $\mathrm{C}$ are more suitable $[25,26]$. On the basis of our investigation, we suggest to use MDRD among liver transplant patients.

\section{References}

[1] Ojo, A. O., Held, P. J., Port, F. K. et al.: Chronic renal failure after transplantation of a nonrenal organ. N. Eng. J. Med., 2003, 349, 931-940.

[2] Fisher, N. C., Nightingale, P. G., Lipkin, G. et al.: P/C13/32 Renal failure in long-term survivors of liver transplantation. J. Hepatol., 1997, 26 (Suppl. 1), 152.

[3] Sanchez, E. Q., Gonwa, T. A., Levy, M. F. et al.: Preoperative and perioperative predictors of the need for renal replacement therapy after orthotopic liver transplantation. Transplantation, 2004, $78,1048-1054$.

[4] Durand, F., Valla, D.: Assessment of prognosis of cirrhosis. Semin. Liver Dis., 2008, 28, 110-122.

[5] Earl, T. M., Cooil, B., Rubin, J. E. et al.: Cost prediction in liver transplantation using pretransplant donor and recipient characteristics. Transplantation, 2008, 86, 238-244.

[6] Hayash, P. H., Forman, L., Steinberg, T. et al.: Model for End-Stage Liver Disease score does not predict patient or graft survival in living donor liver transplant recipients. Liver Transplant., 2003, 97, 737-40.

[7] Kawaguchi, T., Tanaguchi, E., Itou, M. et al.: Body cell mass is a useful parameter for assessing malnutrition and severity of disease in non-ascitic cirrhotic patients with hepatocellular carcinoma or esophageal varices. Int. J. Mol. Med., 2008, 225, 589-94.

[8] Huo, S. C., Huo, T.-I., Lin, H.-C. et al.: Is the Corrected-Creatinine Model for End-Stage Liver Disease a feasible strategy to adjust gender difference in organ allocation for liver transplantation? Transplantation, 2007, 84, 1406-1412.

[9] Kim, R. W., Biggins, S. W., Kremers, W. K. et al.: Hyponatremia and mortality among patients on the liver-transplant waiting list. N. Eng. J. Med., 2008, 359, 1018-1026.

[10] Cardenas, A., Gines, P.: Predicting mortality in cirrhosis - serum sodium helps. N. Eng. J. Med., 2008, 359, 1060-1062.

[11] Lewsey, J. D., Dawwas, M., Copley, L. P. et al.: Developing a prognostic model for 90-day mortality after liver transplantation based on pretransplant recipient factors. Transplantation, 2006, 82, 898-907.

[12] Madero, M., Sarnak, M. J., Stevens, L. A.: Serum cystatin C as a marker of glomerular filtration rate. Curr. Opin. Nephrol. Hypertens., 2006, 15, 610-616.

[13] White, C., Akbari, A., Hussain, N. et al.: Estimating glomerular filtration rate in kidney transplantation: a comparison between serum creatinine and cystatin C-based methods. J. Am. Soc. Nephrol., 2005, 16, 3763-3770.

[14] Marsik, C., Endler, G., Gulesserian, T. et al.: Classification of chronic kidney disease by estimated glomerular filtration rate. Eur. J. Clin. Invest., 2008, 38, 253-259.

[15] Almond, A., Siddiqui, S., Robertson, S. et al.: Comparison of combined urea and creatinine clearance and prediction equations as measures of residual renal function when GFR is low. QJM, 2008, 101, 619-624.

[16] O'Riordan, A., Wong, V.: Chronic kidney disease post-liver transplantation. Nephrol. Dial., $2006,21,2630-2636$ 
[17] Túri, S., Mátyus, J., Kiss, I., Kárpáti, I. (eds): Javaslat a vesefunkció laboratóriumi vizsgálatára felnőttekben. Nephrológiai útmutató. (Suggestion for adult kidney function lab tests. Nephrology guidelines.) (In Hungarian) Medition, Budapest, 2005, pp. 5-9.

[18] Royal College of Physicians: Chronic kidney disease in adults: UK guidelines for identification, management and referral. www.renal.org/CKDguide/full/UKCKDfull.pdf

[19] Mátyus, J., V. Oláh, A., Ujhelyi, L. et al.: Az idült vesebetegség epidémiája szükségessé teszi a glomerulus filtrációs ráta számítását. (The epidemic of chronic kidney disease requires the estimation of glomerular filtration rate.) (In Hungarian) Orv. Hetil., 2008, 149, 77-82.

[20] Delanghe, J. R., Cobbaert, C., Galteau, M-M. et al.: Trueness verification of actual creatinine assays in the European market demonstrates a disappointing variability that needs substantial improvement. An international study in the framework of the EC4 creatinine standardization working group. Clin. Chem. Lab. Med., 2008, 46, 1319-1325.

[21] Seronie-Vivien, S., Bouissou, F., Dattez, S. et al.: Modeling the variability of creatinine measurements improves estimates of the glomerular filtration rate. Clin. Chem. Lab. Med., 2008, 46, 215-218.

[22] Poggio, E. D., Batty, D. S., Flechner, S. M.: Evaluation of renal function in transplantation. Transplantation, 2007, 84, 131-136.

[23] Ruilope, L. M., Zanchetti, A., Julius S. et al.: Prediction of cardiovascular outcome by estimated glomerular filtration rate and estimated creatinine clearance in the high-risk hypertension population of the VALUE trial. J. Hypertens., 2007, 25, 1473-1479.

[24] II. Magyar Terápiás Konszenzus a kardiovaszkuláris betegségek megelőzéséról és preventív kezeléséről. (Second Hungarian Consensus Meeting on the Prevention of Cardiovascular Diseases.) (In Hungarian) Metabolizmus, 2005, IV (Suppl. A), Al-A76

[25] Issa, N., Meyer, K. H., Arrigain, S. et al.: Evaluation of creatinine-based estimates of glomerular filtration rate in a large cohort of living kidney donors. Transplantation, 2008, 86, 223-230.

[26] Cantarovich, M., Yoshida, E. M., Peltekian, K. M. et al.: Poor prediction of the glomerular filtration rate using current formulas in de novo liver transplant patients. Transplantation, 2006, 82, $433-436$. 